\title{
Die herlewing van sekulêre spiritualiteit in Europa en die implikasie daarvan vir die NG Kerk in Suid-Afrika
}

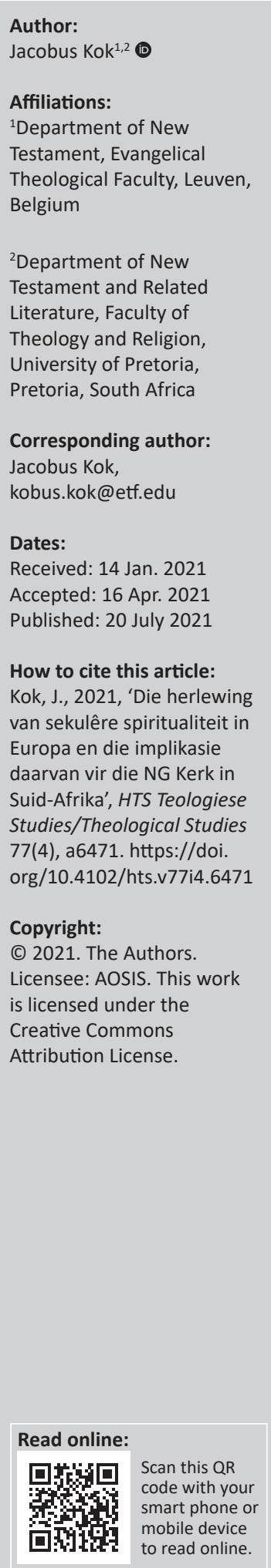

The revival of secular spirituality in Europe and its implication for the Dutch Reformed Church in South Africa. This article critically reflected on the insights of David Tacey in which he notes that there is currently a revival in post-secular spirituality in the West, but that its deep religious roots are lacking. What would be the implication of these trends for the South African religious landscape where traditional mainstream churches such as the Dutch Reformed Church are shrinking significantly? People often say yes to God, but no to the church. Some in the church may totally renounce God. What lessons could be learned by the South African mainstream churches and theology if these trends in the West were taken into account? In this article a critical literature review (desk research) was done and the study was structured as follows: In the first place, the implication of superdiversity, supermobility and the reality of a post-COVID-19 consciousness was discussed. Next we engaged in research by scholars in which it was shown that our time, at least in the West, is characterised by existential anxiety and uncertainty. Thirdly, we engaged in the insights of David Tacey in which he also argued the fact that the uncertainty of the time in which we live, often causes people to return to spirituality. Finally, the implication of these trends for the Dutch Reformed Church in South Africa was reflected on.

Contribution: This research makes a contribution to the nature and scope of the journal, in that it finds that the rise in secular spirituality, in the context of anxiety and uncertainty in a post-COVID-19 world, provides an opportunity for the Dutch Reformed Church to find meaning and significance.

Keywords: spirituality; superdiversity; supermobility; COVID-19; anxiety; meaning and significance.

\section{Inleiding}

Daar is verskeie uiteenlopende definisies van spiritualiteit - elkeen met sy eie problematiek en veronderstellings. In hierdie artikel definieer ek dit in my Sitz im Leben as predikant en teoloog, as 'n subjektiewe ervaring van 'n nie-materiële, buitesensoriese spirituele dimensie, wat integraal en holisties saamhang met die materiële, en wat roep om integrasie van die mens se diepste waardes, lewensbetekenis en singewende geheel. In hierdie siening is ek deur Waaijman (2002) geïnspireer, maar ook deur Schneiders (2000).

In hierdie artikel word daar krities oor insigte van David Tacey gereflekteer - insigte waarin hy opmerk dat daar tans in die Weste 'n herlewing in post-sekulêre spiritualiteit is, maar dat die diepe religieuse wortels daarvan ontbreek.

Wat sou die implikasie van hierdie tendense wees vir die Suid-Afrikaanse godsdienstige landskap waar tradisionele hoofstroomkerke soos die NG Kerk aansienlik krimp? Mense sê dikwels 'Ja vir God, maar nee vir die Kerk' (Kok 2018). Sommige mense in die kerk soos Du Toit (2020), doen totaal afstand van God. Watter lesse sougeleer kon word deur dieSuid-Afrikaansehoofstroomkerke en die Teologie indien hierdie tendense in die Weste in ag geneem word?

In hierdie artikel gaan die volgende proses gevolg word: In die eerste plek word daar 'n bespreking gedoen van die implikasie van superdiversiteit, supermobiliteit en die realiteit van 'n

Note: Special Collection: From timely exegesis to contemporary ecclesiology: Relevant hermeneutics and provocative embodiment of faith in a Corona-defined world - Festschrift for Stephan Joubert, sub-edited by Willem Oliver (University of South Africa). 
post-COVID-19 bewussyn. Vervolgens word aangesluit by navorsing deur geleerdes waarin aangetoon sal word dat ons tyd, minstens in die Weste, deur eksistensiële angs en onsekerheid gekenmerk word. Derdens sal aangesluit word by die insigte van David Tacey, waarin hy ook aansluit by die feit dat die onsekerheid van die tyd waarin ons leef, mense dikwels na spiritualiteit laat terugkeer. Laastens sal gereflekteer word oor die implikasie van hierdie tendense vir die kerk in Suid-Afrika. Hierdie metode van ondersoek verteenwoordig 'n integrerende kritiese literatuuroorsig, waarmee gepoog word om op dié wyse nuwe verbande te trek en nuwe perspektiewe vir dialoog te open.

\section{VOKD-Corona-wêreld}

Daar kan met reg gestel word dat ons in 'n VOKD-Coronawêreld leef: 'volatiel': onseker, kompleks en dubbelsinnig (reds. Kok \& Van den Heuvel 2019). ${ }^{1}$ Dit word wyd aanvaar dat ons tans in 'n globale revolusionêre era leef wat net so 'n geweldige oorgang behels as tussen die Middeleeue en die Moderne era (Barentsen \& Kok 2017:7-10; Kok \& Jordaan 2019:4-5; Van den Broeck \& Jordaan 2018:12). In 2005 het Steven Vertovec die term superdiversiteit vir die eerste keer gebruik, waarmee hy die aard van ons tyd beskryf as ' $n$ fase waarin daar diversiteit binne diversiteit voorkom (Vertovec 2007). Dit gebeur nie net binne samelewings op makrovlak nie, maar ook binne plaaslike gemeenskappe, gesinne en ook binne die individu op mikrovlak. Die digitale en kommunikasierevolusie, asook die gepaardgaande supermobiliteit wat moontlik geword het as gevolg van verbeterings in vervoer, lei daartoe dat mense baie meer beweeglik is in vergelyking met die grootste deel van die geskiedenis tot dusver. Die gevolg is dat mense blootgestel word aan 'n magdom diversiteit en dat die spoed waarteen dit gebeur, ongekend is in vergelyking met vorige tydperke in die geskiedenis. In 'n onlangse boek skryf Geldof (2016) dat superdiversiteit in die toekoms in die Weste gaan toeneem indien daar na migrasiepatrone gekyk word. Dit lei op sy beurt weer na diversiteit binne diversiteit (Kok \& Jordaan 2015:5), asook die onsekerheid wat met hierdie tipe grootskaalse veranderings in die landskap saamhang.

Jordaan (2019), 'n internasionale kenner op die gebied van mediasie, skryf dat die besigheidswêreld deur 'toenemende vlakke van kompleksiteit, turbulensie en onsekerheid' gekenmerk word, en dat daar 'n wesenlike tekort aan 'vertroue' in organisasies is. Dit stel hoë eise aan leiers in organisasies om vorme van vertroue te skep, ten einde die negatiewe effekte van konflik, onsekerheid en eliminerende kompetisie teen te werk. Dit is in hierdie konteks dat kenners in die besigheidswêreld by self-transenderende spiritualiteit aansluit, as 'n poging om transformatiewe leierskap te fasiliteer. Een sodanige voorbeeld is die werk van Louis Fry, 'n deskundige op die gebied van spirituele leierskap (vgl. Fry \& Cohen 2009:265-278). Ander soos Makka (2019:78), 'n geleerde in leierskapsteorie, argumenteer ook oortuigend dat suksesvolle leiers in die toekoms diegene sal wees wat die spirituele dimensie daarvan herontdek, te midde van 'n snel veranderende en onsekere tyd. Maar ten einde daarin te slaag, moet 'n mens ook iets verstaan van die plek waarvandaan ons as gemeenskap kom, en waarheen tendense in die algemeen op pad is.

In 2020 het COVID-19 die wêreldtoneel kom verander. Dit het ongetwyfeld bygedra tot die scenario wat hier bo beskryf is, en dit het tot verdere kompleksiteit en verandering gelei. Meer as ooit besef ons die waarheid dat ons in 'n 'global village' woon, en dat dit wat aan die ander kant van die wêreld gebeur, 'n direkte gevolg het op dit wat aan hierdie kant van die wêreld gebeur. Ook het daar waarskynlik wêreldwyd 'n bewussynsverandering ingetree met die uitbreek en gevolge van COVID-19. Die filosoof Slavoj Žižek (2020) skryf in hierdie tyd 'n boek getitel, Pandemic!: COVID-19 shakes the world, oor die impak wat die pandemie op sy eie denke uitgeoefen het. Die openingswoorde van sy boek begin ironies genoeg met 'n aanhaling uit die Bybel, te wete uit Johannes 20:17. Wat dit interessant maak, is dat Žižek 'n self-erkende 'Christelike Atheïs' is. Maar hier gebruik hy die teks uit Johannes aan die een kant, en Hegel aan die ander kant, om te argumenteer dat ons ander mense dikwels slegs kan 'beleef' indien ons hulle vanaf 'n afstand beleef. Žižek (2020) merk op:

The beloved is not opposed to us, he is one with our own being; we see us only in him, but then again he is not a we anymore - a riddle, a miracle [ein Wunder], one that we cannot grasp. (bl. 2)

Vir Žižek bestaan daar inherent in die realiteit van sosiale afstand (social distancing) miskien die potensiaal dat ons die wonder van die ander kant ontdek, en dat dit die band tussen mekaar in hierdie wêreld kan versterk. Volgens hom deel die wêreld vir die eerste keer in 'n lang ruk weer 'n krisis, en word ons eie broosheid op 'n intense en intensionele wyse beleef. In sy boek betoog hy dat dit nodig is om 'n nuwe wêreldbewussyn te ontwikkel, en droom hy van 'n alternatiewe gemeenskap wat uit hierdie krisis gebore kan word. Vir baie mense sal hierdie boek diep spiritueel voorkom, en iets van die nuwe tydsgees en ontluikende tendense weerspieël.

\section{Oppervlakkige spiritualiteit en angs}

Die Belgiese psigiater Dirk de Wachter (2012) het onder meer in die Laaglande bekendheid verwerf vir sy boek, Borderline times: Het einde van de normaliteit. Volgens hom word die Weste, minstens in België, toenemend deur eienskappe gekenmerk wat eie is aan 'n grensgeval-persoonlikheidstoornis. De Wachter (2012) merk op:

$[W]$ e leven in Borderline Times, niet alleen op medischpsychologisch (en dus psychiatrisch) vlak, maar tegelijkertijd op politiek-sociologisch, antropologisch, cultureel-filosofisch en ethisch-religieus gebied ... In al haar geledingen en dimensies vertoont de maatschappij borderline kenmerken. (bl. 229)

Een van die kernmerke van Borderline is verlatingsangs. In sy eerste hoofstuk beskryf hy die wyse waarom die kontemporêre gemeenskap aan verlatingsangs lei, en beskryf 
ook eksplisiet die opskrif 'De "dood" van God, van het universalisme en fundering', as 'n direkte oorsaak van verlatingsangs. Hy begin sy argument deur na Lyotard te verwys, en dat die postmodernisme gedefinieer kan word as die tydperk van die einde van God en die einde van universalisme en fundering. Natuurlik is die uitdrukking, 'dood van God', lank reeds deur geleerdes soos Nietzsche gebruik. De Wachter (2012:49) merk egter tereg op dat nihilisme 'n direkte gevolg is van die 'absolute sinloosheid' wat voortgevloei het uit die 'dood van God'-bewussyn. Volgens hom is daar duidelike tendense wat hy bespeur nadat hy drie tot vier dekades lank as psigiater werksaam was. Hy bespeur die tendens dat daar 'n geweldige tekort is aan singewing, en dat dit direk saamhang met die 'dood' van God en die verlies van universele sekerhede. Volgens De Wachter (2012:49) blyk dit nie dat die 'dood' van God noodwendig 'n bevrydende en positiewe uitwerking gehad het nie: 'Er wordt door de 21ste-eeuwe mens hard gewerkt om aan te tonen dat we beter af zijn zonder zekerheden' en daar is ook groot twyfel 'of we straks teoreden kunnen terugblikken op het afschaffing van God en geloof, en blij zullen zijn om onze vernieuwde status van kritisch denkend wezen'. Hy merk op dat die wegval van God, die mens met noemenswaardige probleme gelos het, en dat verlatingsangs maar net een van die gevolge daarvan is. In die proses waarin individualisme as't ware universalisme onttroon het, het dit ongelukkig ook gelei tot die gevoel van fundamentele verbrokkeling, verlies, leegte, eensaamheid en algemene sinloosheid (De Wachter 2012:50). Die gevolg van hierdie verbrokkeling is ook dat die skep van identiteit skade lei en lei tot 'n verlies van fundering en geworteldheid, asook tot 'n gevoel van verlatingsangs (De Wachter 2012:51). Die bevindings van De Wachter kom ooreen met ander soos Paul Verhaeghe. Lg merk op: 'De moderne mens is niet verdeeld, hij is verbrokkeld' en dat die gemeenskap 'n vorm van patologie vertoon. In sy boek stel De Wachter dat die 'dood van God' 'n negatiewe uitwerking gehad het op die algemene gesondheid van die samelewing, hy wend egter nie' $n$ poging aan om enige vorm van terugkeer na God te bespreek nie.

'n Ander geleerde, David Tacey, wat in sy navorsing die herlewing van spiritualiteit in ons unieke tydperk in die geskiedenis bespreek, word vervolgens ondersoek.

\section{Die terugkeer van spiritualiteit en worstelinge met ons eie demone}

In Nederland is daar, anders as in België, by die meeste hospitale 'n betaalde funksie geskep van 'Geestelijke Verzorgers'. Dit is onder meer die taak van geestelike versorgers om pasiënte by te staan tydens krisistye in hulle lewe.

Aan die Vrije Universiteit te Amsterdam word daar al 'n geruime tyd 'n meestersgraad met spesialisering in 'Geestelijke Verzorging' aangebied. In die kurrikulum word daar onder meer van die Oxford Textbook for Public Health onder die redakteurskap van Cobb en andere gebruik gemaak. Daarin verskyn 'n hoofstuk deur David Tacey. In die bespreking wat volg, word 'n kritiese oorsig verskaf van die insigte van Tacey en ook aangetoon hoe dit aansluit by dit wat hier bo bespreek is.

In sy hoofstuk argumenteer hy dat ons tans in die Weste in 'n post-sekulêre tydperk leef. Dit is gemeenplaas dat in die sekulêre tydperk 'n afkeur bestaan het aan alles wat 'spiritueel' was. ${ }^{2}$ Tacey (2012:477) merk ook soos De Wachter en ander op, dat die modernistiese projek en sekularisasie in die algemeen uiteindelik tot nihilisme en die verlies van betekenis ('absence of meaning') gelei het. Tacey (2012) verwys na Peter Berger in sy opmerking:

The earlier sociological view held out little hope for religion and adhered to the theory of secularization, which argued that as we become more educated, belief in God and the spiritual would disappear. However, the contemprary view has refuted this theory, in keeping with the fact that religion is not going away, but is changing its shape and reappearing as 'spirituality'. (bl. 477)

Dit wil voorkom asof daar in die meeste van die Westerse demokrasie tans ' $n$ tendens is dat religie en religieuse instansies kwyn (reds. Boersema \& Paas 2011). Aan die ander kant is daar ' $n$ herlewing in en 'n behoefte aan spiritualiteit. Sandra Schneiders (2000) stem hiermee saam en merk op: 'If religion is in serious trouble, spirituality is in the ascendency ...' Caputo (2001) stem ook hiermee saam en argumenteer oortuigend dat in die hoogbloei van sekularisme, daar 'n sekere mate van tekort was in diepgaande ervarings. Postsekularisme verteenwoordig in vele opsigte 'n terugkeer na spiritualiteit tot so 'n mate dat dit 'n dominante tendens word. Maar hier moet daarop gelet word dat die terugkeer na spiritualiteit 'n post-Christelike karakter het. Dit beteken dat dit 'n spiritualiteit is wat dikwels deur kerklikes beskryf word as sekulêre of nie-religieuse spiritualiteit. Tacey (2012:473) beskryf dit as 'n 'spiritual revival', maar waarsku dat hierdie herlewing in spiritualiteit vergelyk kan word met blomme wat op ' $n$ tafel geplaas word. Sodanige blomme is wortelloos en verlep gou. Tacey waarsku dat hy van mening is dat hierdie tydelike herlewing nie ' $n$ gewortelde herlewing is nie en waarskynlik nie die toets van die tyd sal weerstaan nie, omdat dit 'n vlak spiritualiteit behels. Tacey (2012) stel dit soos volg:

The flower of spirituality might wilt and die when its day passes, unless it can find its way back to the sources from which it arose. In my reckoning, those sources must include the religious and metaphysical traditions of the past. In denying its origins in religion, modern spirituality might be cutting itself off from its own continued survival. (bl. 473)

In die vervolg van sy argument, betoog David Tacey dat die opkoms van spiritualiteit al meer populêr word omdat daar by mense ' $n$ wesenlike behoefte daaraan is, en dat dit direk saamhang met die problematiek rondom geestelike leegheid.

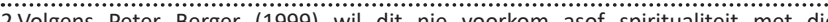
sekur sekularisme verdwyn het nie. Inteendeel, daar is 'n herlewing en behoefte aan spiritualiteit. Maar tog is dit belangrik om te let op die wyse waarop spiritualiteit aan die verander is, en daar moet kreatiewe pogings aangewend word om aan hierdie behoeftes te voldoen. 
Die probleem is egter dat die opkoms van spiritualiteit in ons tyd, nie erns maak met die geskiedenis en agtergrond waarin dit ingebed is nie. Tacey (2012:474) is van mening dat daar oor die algemeen 'n vervlakking plaasgevind het in spiritualiteit, en dat dit in 'n sterk verbruikersmentaliteitskonteks ontstaan het. Net soos Dirk de Wachter (2012) opgemerk het, word ons tyd gekenmerk deur angs, wat die aard van spiritualiteit en die soeke daarna beïnvloed. Tacey (2012) merk op:

The human spirit today is half-starved, undernourished, dessicated, and full of anxiety, so when it finally appears it comes with considerable claims and a baggage of historical neglect. (bl. 474)

Die probleem is dikwels dat New-Age spiritualiteit dikwels gebruik maak van simbole uit tradisies wat geïdialiseer word. So word 'dream catchers' op flooimarkte gevind en dit kom uit die erfgoed van 'Amerindian peoples' maar sonder enige diepte. So word daar byvoorbeeld geensins rekening gehou met die vernietigende effek wat koloniale magte op sulke groepe gehad het nie. Hulle simbole word onkundig en oppervlakkig gebruik sonder die dieper dimensies wat in hierdie kulture en gelowe voorkom. Die industrieë wat hierdie simbole vervaardig, lei aan 'n vorm van religieuse en kulturele amnesie. Hierdie tipe New-Age spiritualiteit word op so 'n wyse gebruik, dat dit 'n sekere vorm van ontvlugting van die wêreld behels. Tacey (2012:474) wys tereg daarop dat '[s]pirituality is not merely a flight from the real or an escape from history, but a movement more deeply into history'. Hierdie dieper dimenise veronderstel dat ons soos Rohr (2011:xiii, 8, 21, 58, 73, 161,173) (lg. geïnspireer deur C.G. Jung en Thomas Merton), moet uitkom by 'n plek waar die outentieke self buite die grense van die selfsugtige ego ontdek word. Dit behels heel dikwels dat 'n mens ver buite die plesierbeginsel moet beweeg. Tacey (2012) merk op:

If people realized how difficult spirituality is they would not idealize it or pretend it is some kind of fun park for the soul. To become spiritual is to encounter forces that are outside the control of the ego and beyond the pleasure principle. To encounter spirit is to discover an authentic self which is likely to make real demands on us. (bl. 474)

In hierdie konteks gebruik Tacey dan die woord metanoia om aan te toon dat hierdie tipe spiritualiteit ' $n$ omwenteling van die persoon vereis, en dat dit onlosmaaklik saamhang met opoffering en ' $n$ proses waarin 'n mens gekonfronteer word met jou 'eie demone' of donker kante. Hy (Tacey 2012) haal die digter W.B. Yeats se laaste gedig aan wat soos volg lui:

Now that my ladder's gone

I must lie down where all the ladders start

In the foul rag and bone shop of the heart. (bl. 475)

Dit is in die konteks van dit wat De Wachter en andere as die eksistensiële ervaring van die 'dood van God' beskryf, dat die mense wat hierdie diepe spirituele reis onderneem, dikwels ook besef dat hulle nie kan wegvlug van die diep psigologiese realiteit van hulle eie bestaan nie. Die mens word helaas teen sy wil in die dampkring van die onbewuste gewerp waar hulle hul eie skadu's en trauma moet konfronteer
(Steenkamp 2018:127-135). Dit is juis hier waar die mens opnuut besef dat daar ' $n$ diep behoefte is aan ' $n$ vorm van restourasie en heelheid (Steenkamp 2018:189-210).

Hierby sluit die Jungiaanse geleerde James Hollis (2005) ook aan. In sy boek, Finding Meaning in the Second Half of Life, beskryf hy ook hierdie proses waarby die mens moet kom om sin te maak van die tweede helfte van die lewe waarin hierdie tipe eksistensiële belewenisse voorkom. Volgens Hollis gebeur dit dikwels in noemenswaardige krisistye, en in groot oorgangstye (soos middeljare of aftrede), dat mense met projeksies wat verbrokkel gekonfronteer word en gevolglike rou, verlies en skuldgevoelens ervaar. Dan word die mens genoodsaak om opnuut te reflekteer en neig mense dan dikwels na 'n behoefte aan dieper spiritualiteit (Hollis 2005).

Volgens David Tacey (2012:475) het die huidige oplewing in spiritualiteit veral te make met prosesse van ontdekking op die vlak van 'siel' (soul) meer as 'gees' (spirit), in die sin dat 'soul' by die Griekse idee van psyche of die interne van die mens aansluit. Dit hang dus ten nouste saam met dit wat Jung individuation noem (Huysamen 2016:53). In hierdie sin het spiritualiteit te make met 'connecting to the heart, locating the inner self, relating to cosmic forces and attending to dreams' (Tacey 2012:475). Dikwels is dit ook hier waar tradisionele religieuse persone die reis van diegene wat hulle in die soeke na moderne spiritualiteit bevind, misverstaan, meen Tacey. Ongelukkig is dit ook so dat kontemporêre spiritualiteit dikwels 'n sterk narsistiese karakter het, omdat dit veral oor die aktualisering van die self gaan (sien Hanegraaff 1996). In hierdie verband wys Tacey (2012:475) heeltemal korrek op die feit dat hierdie narsistiese aard van spiritualiteit, nie reg aan die diepte van die tradisies waaruit dit put, laat geskied nie. In die geloofstradisies, veral in die Christendom, het spiritualiteit ten diepste gegaan oor die neerlê van die self en die oorgee aan God. In teenstelling, gaan dit vandag meer oor die self en minder oor die betekenisvolle Ander waaraan oorgegee word.

Aan die ander kant oortuig Tacey se argument, naamlik dat die tradisionele religieuse belewenis van spiritualiteit ongelukkig ook 'n dualisme skep, wat problematies kan wees. Soos daar gesien kan word in die woordeboekdefinisies van spiritualiteit, word spiritualiteit onderskei van dit wat 'materieel' is. Spiritualiteit word verstaan as dit wat nie-fisiek is nie. Liggaam staan teenoor gees, bo teenoor onder, en dit wat spiritueel is, in kontras tot die materiële en die natuur. Hierdie tipe definisies gaan terug op 'n dualistiese wêreldbeeld (Du Toit 2020). Die probleem is dikwels dat tradisionele religieuse verteenwoordigers wat spiritualiteit sodanig verstaan, negatief staan teenoor moderne benaderings wat die dualisme tussen die spirituele en 'nie-spirituele' ophef. Hierdie opheffing van dualiteit is ook kenmerkend in Oosterse spiritualiteite, en laasgenoemde vorm die basiese struktuur van kontemporêre spiritualiteite. Verder is tradisionele (Christelike) benaderings ook meer geneig om 'n sondeval-paradigma te handhaaf, waarvolgens die mens inherent korrup is en geneig is tot die kwaad. Hiervolgens 
word geglo dat diep geestelike belewenisse alleen bereik kan word as 'n mens hierdie slegte natuur gekruisig het. Hierteenoor stel kontemporêre spiritualiteit wat voortvloei uit 'n Oosterse denkraamwerk dat mense inherent geskep is na die beeld van God en inherent goed geskep is. Deur dieper te delf in die self, word die lig wat deur die Skepper daar geplaas is, ontdek - en die self word dus die pad waarlangs God ontdek word. Die self word dus nie as fundamenteel sleg beskou nie, maar as die hoogs potensiële weg waarlangs die 'heilige' ontdek kan word. Daarom maak dit ook logies sin dat kontemporêre spiritualiteit nie 'n dualisme en skeiding tussen liggaam en gees handhaaf nie. In tradisionele Christelike spiritualiteit word seksualiteit as iets korrups beskou wat die mens van God weerhou. In kontemporêre spiritualiteit, is seksualiteit dikwels die plek waar dimensies van die goddelike ontdek word. In kontemporêre spiritualiteit vloei die denke meer in die rigting van 'non-dualisme' en 'heelheid' (wholeness). 'n Mens sien dit ook in definisies van spiritualiteit soos dié van Peter van Ness soos aangehaal deur Tacey (2012:476): '[T]he desire to relate oneself as a personal whole to reality as a cosmic whole'. Hierdie siening roep na 'n belewenis van 'embodied integration'. Sandra Schneiders (2000) het 'n soortgelyke definisie van spiritualiteit, en beskryf dit as '[A]n effort to bring all of life together in an integrated synthesis of ongoing growth and development'. Vir Schneiders gaan dit om die totale heelheid van die totale mens in alle dimensies, synde fisiek, emosioneel, sosiaal, en so meer. Hiervolgens verstaan 'n mens ook dat die tema van genesing, restourasie en rekonsiliasie 'n belangrike rol sal speel, in die sin dat kontemporêre spiritualiteit ' $n$ diepe soeke behels om die gevoel van disintegrasie en fragmentasie (soos hierbo bespreek aan die hand van De Wachter) te hanteer.

In sy logiese argumentatiewe styl gaan Tacey verder, deur die punt te maak dat nadere ondersoek aantoon dat kontemporêre spiritualiteit 'n post-Christelike aard het. Hy argumenteer dat die Westerse tradisies oor die algemeen nie die vermoë het om mense te help wat die proses deurloop, om die onbewuste te verken nie (Tacey 2012:475). In teenstelling hiermee, wil dit voorkom of Oosterse spiritualiteit wel die vermoë het om ruimte te maak en taal te gee aan hierdie tipe belewenisse. Volgens Tacey staan die Westerse religieë by 'n kruispad en is dit nou van kardinale belang vir die oorlewing daarvan dat dit die dit die vermoë ontwikkel om mense deur bogenoemde prosesse te begelei. Tacey (2012) merk op:

Western religions if they want to survive, must befriend the soul and attempt to guide people into the human experience of God. The keynote of contemporary spirituality is experience, and traditions that fail to offer a pathway of experience can expect to decline or diminish

However, when religions understand that people want experience and not preaching, transcendence and not God-talk, a bridge between contemporary spirituality and traditional religion will be found. (bl. 475-476)

'n Persoon wat myns insiens daarin slaag om hieraan aandag te gee, is die bekende teoloog Richard Rohr. In die volgende gedeelte word die werk van Rohr krities bespreek.

\section{Herontdekking van mistieke tekste uit die Middeleeue Inspirasie uit Richard Rohr se werk}

Teen die agtergrond van wat hierbo geskets is, sluit baie mense deesdae aan by die mistieke tekste van die Middeleeue. Die bekende teoloog Richard Rohr, skryf in die openingsrede van sy boek, Falling Upward, dat hy glo dat God aan ons almal individueel 'n 'unique blueprint' (sy beskrywing van die siel) gegee het wat 'ontdek moet word'. Hy haal dan vervolgens 'n gedig aan deur Gerard Manley Hopkins wat deur die Middeleeuse mistieke denker, Duns Scotus (1265-308), geïnspireer is. Rohr (2011) merk op:

Life is indeed 'momentous', created by accumulated moments in which the deeper ' $\mathrm{I}$ ' is slowly revealed if we are ready to see it. Holding our inner blueprint, which is a good description of the soul, and returning it humbly to the world and to God by love and service is indeed of ultimate concern. (bl. xi)

Op verskeie plekke in sy boek wend Rohr (2011:8, 91, 107, 134) hom tot die insigte van Teresa van Avila. In sy boek sluit hy dikwels aan by Jung se gedagte van twee helftes van die lewe en die soeke na sin en betekenis. Hy argumenteer dan dat die mens universeel 'n soeke het na 'n 'tuiskoms'. Rohr (2011) glo dat hierdie tuiskoms 'n geestelike soeke verteenwoordig en merk op:

$[H]$ ome is another word for Spirit that we are, our True Self in God. The self-same moment that we find God in ourselves, we also find ourselves inside God, and this is the full homecoming according to Teresa of Avila. (bl. 90-91)

Tot tyd en wyl hierdie ervaring nie gebeur nie, sal mense 'n gevoel van home-sickness beleef wat verkeerdelik beleef kan word as eensaamheid, isolasie, hartseer, rusteloosheid en selfs depressie (Rohr 2011:91).

Rohr wend hom vervolgens tot die Skrif, en argumenteer op grond van Johannes 14:18 dat gelowiges nie alleen gelaat word nie, maar dat daar alreeds ' $n$ trooster bestaan, en dat die Gees uit liefde aan ons gegee is ( $\mathrm{Rm}$ 5:5). Rohr argumenteer verder dat dit die Geestelike advokaat is wat die mens na ' $n$ tuiskoms begelei. Op meesterlike wyse sluit Rohr aan by die 'waarheid' in mites en verhale oor kulture en verskillende tydperke heen (soos Homeros), waarin 'n diepe begeerte en verlange na 'tuiskoms' en 'heelheid' of 'genesing' bestaan (Rohr 2011:92-93). Hy toon dan aan hoe die 'antwoord' op hierdie diepe begeertes inherent in die Skrif voorkom. Volgens Rohr (2011:94) is hierdie innerlike rusteloosheid iets wat eie is aan mense in alle kulture en oor tyd heen. Dit is iets wat God in die mens geplaas het. Hy merk op: 'God creates the very dissatisfaction that only grace and finally divine love can satisfy' (Rohr 2011:95). Vervolgens redeneer hy dat diegene wat al by 'n sterfgeval betrokke was en gesien het hoe iemand hierdie lewe verlaat, sal besef dat daar 'n vorm van misterie en skoonheid aan so 'n proses is. Daaragter lê iets 'werkliks', argumenteer Rohr, en merk op: 'This "something real" is what all the religions were pointing to when they spoke of heaven, nirvana, bliss, or enlightenment'. Vervolgens skryf hy in 
hoofletter van die 'Real' wat vir ewig sal wees, en iets is wat nog altyd deel van die mens se gekiedenis en daarvóór was. In 'n interessante wending in die argument, draai Rohr (2011:96) na Johannes 4:14 en meen dat die Samaritaanse vrou lewe ontvang het van Jesus, en dat Hy aan haar gewys het dat hemel, gemeenskap, liefde, en Lewe iets is wat nie van buite kom in die vorm van sisteme nie, maar dat dit vanuit die

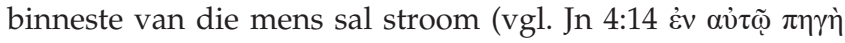

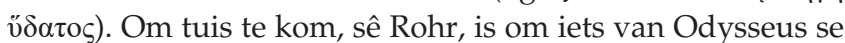
waarheid te besef. Hy haal die Egiptiese digter C.P. Cavafy se gedig Ithaca in sy eie vertaling daarvan, aan:

Ithaca has now given you the beautiful voyage.

Without her, you would never have taken the road,

With the great wisdom you have gained on your voyage,

With so much of your own experience now,

You must finally know what Ithaca really means. (Cavafy soos vertaal deur Rohr 2011:96)

In vele klassieke literatuur en ook resente televisieprogramme (vgl. byvoorbeeld die karakter van Jamie in die reeks Outlanders), sentreer die verhaal rondom 'n individu, dikwels van adellike of koninklike afkoms, wat nie besef wat hulle ware identiteit is nie. Die plot sentreer dan rondom die proses waarin die individu uiteindelik hul ware identiteit besef. Rohr (2011:97-98) meen dat dit ook die geval is met mense wat nog nie besef dat hul ware identiteit in God te vinde is nie. Volgens hom het die Christendom in die Weste, wat aan 'n vorm van amnesie ly, die taak om mense te help om die ontdekking te maak van hulle Ware Self (let op na die hoofletters by Rohr). Volgens hom het die Oosterse Christendom (vgl. Theosis) in die geskiedenis hierdie gedagte beter ontgin as die Westerse Christendom.

Weereens maak Rohr (2011:103) 'n interessante wending in sy argument. Hy merk op dat dit wat universeel in die ervarings van mense is soos alreeds hier bo genoem, ten diepste teen die einde tot 'n behoefte aan eenvoud en versoening lei. Hy wend hom dan tot Ken Wilber se werk en merk op: '[T]he classic spiritual journey always begins elitist and ends egalitarian. Always!' Volgens hom sien 'n mens dit in Judaïsme wat eksklusief begin, maar in profete eindig wat eksklusiewe grense in die Christendom oorbrug, wat dan begin as 'n klein sekte en eindig as 'n kerk met universele ('catholic', of 'universal') gerigtheid, in Sufi Islam en Hindu Krishna-bewussyn wat God se vreugde oral sien (Rohr 2011:103). Vervolgens sluit hy aan by die mistieke skrywers in die Christelike tradisie, en noem die werk van William Blake en Lady Julian, wat begin het met 'n sandkorrel en geëindig het met 'n oseaan van oneindigheid. Dan merk Rohr (2011:103) ook op: 'Life moves first toward diversity and then toward union of that very diversity at ever higher levels'.

Later in sy boek, hanteer Rohr die kwessie van niedualisme. In aansluiting by Jung en andere, meen hy dat dit belangrik is dat ' $n$ mens die vermoë ontwikkel om jou lig en jou skadus te omhels (Rohr 2011:134). Volgens hom kan 'n mens ander eers waarlik liefhê, indien jy die diepe kante van jou eie skadu ontdek het en ' $n$ vorm van mededoë met jouself ontdek het. Jy moet ook besef dat die een nie die ander uitsluit nie. Dan sien 'n mens ander mense ook anders, en ontwikkel jy eers die vermoë om nie net genade vir die self nie, maar ook vir ander te hê. Rohr (2011) maak in hierdie konteks die volgende belangrike opmerking:

Here you understand the absolute importance of contemplative or non-dualistic thinking. ... The gift of shadowboxing is in the seeing of the shadow and its games, which takes away much of the shadow's hidden power. No wonder that Teresa of Avila said that the mansion of true self-knowledge was the necessary first mansion. Once you have faced your own hidden or denied self, there is not much to be anxious about anymore, because there is no fear of exposure - to yourself or others. (bl. 134)

Die tweede helfte van die lewenspiritualiteit het die vermoë om ruimte te skep, en diegene wat diep deur hierdie prosesse beweeg het, skep dikwels 'n nieveroordelende ruimte vir ander (Steenkamp 2018:244-245). Volgens Rohr en andere is dit nou meer as ooit nodig dat die Christelike kerk erns daarvan moet maak om nie-veroordelende ruimtes vir dialoog, begrip en wysheid te skep. Dit het reuse implikasies vir die kreatiewe kerkwees in ons tyd, ook in Suid-Afrika.

\section{Uitdagings in die NG Kerk in die 21ste eeu \\ Ben du Toit en sy boek: 'God: is daar ' $n$ ander antwoord?'}

Reeds in die vorige eeu het die insigte van prof. Kuitert na sy aftrede skokgolwe deur die Nederlande geloofsgemeenskap gestuur (Kuitert 2002). Dit is as skokgolwe beleef omdat dit die eerste keer was dat 'n binnestander in die kerk self, die konsep van God, soos uitgedruk deur die Christelike geloof as totaal uitgediend vir die moderne mens sou beskou.

Pas in 2020, 'n geruime tyd na sy aftrede, verskyn Ben du Toit se boek, 'God: is daar' $n$ ander antwoord?', waarin hy uiteindelik in sy ontnugtering met die kerk en teologie, uitkom by 'n plek waar hy self verklaar dat hy homself tans in 'n ateïstiese posisie bevind. Hy verkies egter om die term post-teïsties vir homself te gebruik. Kok (2020) skryf in sy resensie van die boek die volgende:

['n] Mens moet met deernis luister na iemand soos Ben du Toit en die diep, seer en traumatiese reis wat hy by wyse van spreke deur James Hollis se 'Dark Wood' ondergaan het, probeer begryp. [O]ok moet mens respek hê vir die wyse waarop hy tans die moed het om sy huidige oortuigings op die tafel te plaas. $[D]$ ie boek se insigte gaan die meeste mense ontstel en selfs teleurstel. Daar gaan wel 'n klein minderheid wees wat nuwe taal, nuwe raamwerke en nuwe metafore gaan ontvang waarin hulle die woorde gaan kry om hulle eie sterwende belewenis met die kerk en God mee te kan beskryf. Ek dink dat die boek baie gevaarlik vir sommige mense kan wees in die sin dat dit die woorde en gedagtes gee wat mens net een pad gaan vat - en dit is om tot ongeloof en ontnugtering te kom. As dit die trajek is waarheen jou reis gaan, gaan hierdie boek soos met 'n waterval jou afvoer oor die kruin en jou laat neerplons in die woelige water daar onder. Daarna sal jy waarskynlik nooit weer bo op die waterval kan kom nie omdat dit 'n 'matrix' waterskeidingsmoment vir jou gaan behels. (ad loc) 
Jean Oosthuizen (2020) het die inisiatief geneem om 'n aanlyn onderhoud met Du Toit te voer. ${ }^{3}$ In hierdie onderhoud verskaf Du Toit belangrike inligting ter verheldering van die boek. Vir Du Toit was dit noemenswaardig bevrydend om konseptueel en emosioneel bevry te wees van 'n denkraamwerk waarvolgens een of ander persoonlike Godheid sy noodlot bepaal. Vir hom het die bybelse boodskap, wat inherent in 'n drieverdieping-wêreldbeeld geskryf is, en waarvolgens 'n bonatuurlike wese genaamd God bestaan, geen sin meer gemaak nie. Hy vind homself deesdae eerder dat hy verwondering buite God om, in die mens en in die natuur ontdek. En hy verklaar dat 'n mens daarvoor nie 'n God nodig het nie. Vir hom bestaan God nie meer nie. Net soos die boek van Kuitert, sal hierdie boek skokgolwe deur die NG Kerk laat gaan, veral omdat dit deur ' $n$ gerespekteerde voormalige leier in die moderamen van die NG Kerk geskryf is.

Kok (2020), in sy resensie van Du Toit se boek, merk op dat hierdie worsteling met God ook in kuns uitgedruk word, en hy merk op:

In een van Leonard Cohen se liedere (Treaty) in sy album 'You want it darker', beskryf hy sy ontnugtering en wegbeweeg van God. Tog was Cohen tot en met sy dood in sy liedere altyd besig met God wanneer dit ten diepste saakmaak. Miskien omdat dit so diep in sy DNA sit. In sy lied Treaty, 'n twee-vlak narratief (oor romantiese liefde en oor God), skryf hy die volgende: 'Ek is altyd moeg en kwaad', en 'Ek is jammer vir die spook wat ek jou (of U) gemaak het, want al wat regtig was, was ek'. Dis die aard van die ontnugtering as mens besef jou projeksies was net projeksies en al wat oorbly is jý. Maar daardie ontdekking laat mens soms voel soos die slang in die paradys, skryf Cohen. In 'n pragtige metafoor skryf hy dat die slang op 'n dag sy sonde besef het. Toe besluit die slang om eerder te vervel, maar in die proses ontdek hy die ware slang aan die binnekant. In sy vervelling besef hy hy is nuut gebore, maar dié keer sonder die vel en nou drup die gif oral uit en vergiftig alles. Dis die ding, die ontnugtering is nie altyd antropologies bevrydend en hoopvol vir alle mense nie. Maar miskien is dit nie almal se belewenis nie, maar die belewenis van diegene wat nie hulle proses van genesing uit trauma voltooi het nie en worstel met die ou reste van die ou dualistiese antropologie. (ad loc)

Vir Kok (2020) laat die boek hom ontnugter, sinies en gestroop voel. Ook Wilhelm Jordaan (2020), wat bekend is vir sy kritiese denke, merk op dat die boek hom ongemaklik leeg laat voel en dat hy van mening is dat dit getuig van diepe ontnugtering en dat verwondering ontbreek.

Uiteindelik gaan die NG Kerk in Suid-Afrika, net soos in Nederland en België, die pad moet stap van 'n groeiende hoeveelheid mense wat in hulle denke vervreemd van die kerk gaan voel. Tog moet 'n mens ook erns neem met die gevolge daarvan. Die Belgiese psigiater, prof. Dirk de Wachter (2012) (self ook 'n ongelowige), skryf in sy boek Borderline Times, dat hy in die verloop van sy akademiese en kliniese loopbaan die ontwikkeling bespeur het, waarin die Godsbegrip van Belge en mense in Europa gekwyn het (sien ook Kok 2020). Hy is van mening dat dit ook met aansienlike verlies gepaard gegaan het. Hy merk op dat postmodernisme saamhang met die einde van God, maar soos hierbo reeds genoem is, het dit tot 'n grootskaalse sinloosheid en nihilisme gelei. De Wachter (2012:50) merk op: 'Het wankelen en wegvallen van het geloof in God heeft ons met gigantische problemen opgezadeld, en verlatingsangst is zeker niet het kleinste'. Hy stel dit eksplisiet dat die individualisme die universalisme van sy troontjie afgestoot het, maar dat dit direk in sy ervaring in die praktyk oor ' $n$ tydperk van dertig jaar, duidelik blyk dat mense meer as ooit ly aan 'n gevoel van verbrokkeling, leegheid en sinloosheid (De Wachter 2012:50). Volgens hom bied die kontemporêre bevredigingskultuur nie antwoorde op hierdie diep eksistensiële vraagstukke van die mens nie.

\section{Konklusie}

In Suid-Afrika sê baie mense steeds 'Ja vir God, maar nee vir die kerk' (Kok 2018). Oudpredikante soos Du Toit (2020) gaan selfs so ver om geloof in God totaal te laat vaar. Du Toit se posisie is uiteindelik nie veel anders as dit wat reeds in Nederland gebeur het nie (vgl. Kuitert). Die vraag is egter wat ná 'n Kuitert en 'n Du Toit kom.

De Wachter (2012) en andere soos Verhaeghe (2009), toon aan dat daar ' $n$ verbrokkeling in die Westerse mens se psige is. De Wachter (as ongelowige) in die besonder, meen dat die feit dat die Weste die rug op God gekeer het, daarmee saamhang. Dit versterk die gevoel van ontworteling, angs en betekenisloosheid. In hierdie artikel het ons vervolgens krities gereflekteer oor die insigte van David Tacey en ook andere wat opmerk dat daar minstens in die Weste ' $n$ vorm van herlewing in spiritualiteit, of 'n soeke daarna ontstaan. Dit gebeur teen die agtergrond van dit wat hy ook as 'n tyd van onsekerheid en ontworteling beskryf.

Dit is in hierdie lakuna dat die kerk geroep word om deel te neem aan 'n gesprek wat sekerlik ook in Suid-Afrika in die toekoms, belangrik gaan wees. Vir die NG Kerk in die besonder, sal daar dus in die toekoms die noodsaak wees om ernstig te besin, in teorie en praktyk, oor die algemene tendense in die samelewing, asook die reaksie van die tradisionele hoofstroomkerke in hierdie verband. Miskien moet 'n mens ook versigtig wees om van hoofstroomkerke te praat, asof die Afrikaanse kerke nog die amptelike kerke van die amptelike geloof in Suid-Afrika is. Myns insiens het ons daardie posisie verloor. Die tradisionele Afrikaanse kerke in Suid-Afrika verteenwoordig deesdae die minderheid, en na alle waarskynlikheid gaan dit in die toekoms verder kwyn (Kok 2018). Maar dit skep ook die geleentheid vir kleiner geloofsgemeenskappe, wat dit kan waag om veel dieper ondersoekend om te gaan met kontemporêre spiritualiteit, om die brug te bou tussen ons diep en klassieke teologie, en kontemporêre tendense en skuiwe in die samelewing. ${ }^{4}$ Dit sal belangrike implikasies inhou vir ekklesiologie, dialogiese ruimteskeppende leierskap, en kontemporêre spiritualiteit.

4.Volgens $\mathrm{Nel}$ (2020) staan Suid-Afrika met betrekking tot fundamentalistiese Charismatiese Kerke in Afrika voor die uitdaging, om ook weer nuut hulle wortels in Charismatiese Kerke in Afrika voor die uitdaging, om ook weer nuut hulle wortels in
die ryke mistiese tradisie van die Charismatiese Kerk se geskiedenis te herontdek, wat dan taal sal verskaf aan kontemporêre belewenisse. 


\section{Erkenning \\ Mededingende belange}

Die skrywer verklaar dat hy geen finansiële of persoonlike verbintenis het met enige party wat hom nadelig kon beïnvloed in die skryf van hierdie artikel nie.

\section{Outeursbydrae}

J.K. was die enigste skrywer van hierdie artikel.

\section{Etiese oorwegings}

Hierdie artikel volg alle etiese standaarde vir navorsing sonder direkte kontak met mens of dier.

\section{Befondsing}

Die outeur is 'n NRF B3-gegradeerde navorser en ontvang befondsing van die NRF en die Universiteit van Pretoria in sy kapasiteit as buitengewone professor.

\section{Data beskikbaarheidsverklaring}

Data-deling is nie van toepassing op hierdie artikel nie, aangesien geen nuwe data in hierdie studies geskep of ontleed is nie.

\section{Vrywaring}

Die sienings en menings wat in hierdie artikel uitgedruk word, is dié van die skrywer en weerspieël nie noodwendig die amptelike beleid of posisie van enige geaffilieerde agentskap van die skrywer nie.

\section{Bronnelys}

Barentsen, J. \& Kok, J., 2017, 'Leadership, (super)diversity and identity construction', in J. Barentsen, S. Van den Heuvel \& V. Kessler (reds.), Increasing diversity: Loss of control or adaptive identity construction?, bl. 3-18, Peeters, Leuven. (CPLSE 5).

Berger, P., 1999, The desecularization of the world, resurgent religion and world politics, Eerdmans, Grand Rapids, MI.

Boersema, P. \& Paas, S. (reds.), 2011, Onder spanning: Een veelzijdige kijk op veranderingen in kerk en samenleving, Kok, Utrecht.

Caputo, J., 2001, On religion, Londen, Routledge.
De Wachter, D., 2012, Borderline times: Het einde van de normaliteit, LannooCampus, Leuven.

Du Toit, B., 2020, God: Is daar 'n ander antwoord? Lapa (Wenkbrou) uitgewers, Pretoria.

Fry, L.W. \& Cohen, M.P., 2009, 'Spiritual leadership as a paradigm for organizational transformation and recovery from extended work hours cultures', Journal of Business Ethics 84(2), 265-278.

Geldof, D., 2016, Superdiversity in the heart of Europe, Acco, Leuven.

Hanegraaff, W.J., 1996, New age religion and Western culture, Brill, Leiden.

Hollis, J., 2005, Finding meaning in the second half of life, Avery Publishing Group, New York, NY.

Huysamen, F., 2016, Jung and you, Individual Jugian Publishing, Pretoria.

Jordaan, B., 2019, 'Leading organizations in turbulent times', in J. Kok \& S.C. van den Heuvel (reds.) Leading in VUCA world: Integrating leadership, spirituality and discernment, bl. 59-76, Springer, Cham.

Jordaan, W., 2020, 'nuwe geloof in data ... en ook in jouself', Netwerk 24, Menings, 25 November 2020, besigtig op 08 Januarie 2021, vanaf https://www.netwerk24. com/Stemme/Menings/nuwe-geloof-in-data-en-ook-in-jouself-20201124

Kok, J., 2018, Ja vir God, Nee vir die kerk, CarpeDiemMedia, Vereeniging.

Kok, J., 2020, 'Het Ben du Toit as dominee uiteindelik gekies vir die slang?', Maroela Media, besigtig op 08 Januarie 2021, vanaf https://maroelamedia.co.za/afrikaans/ boeke/resensie-het-ben-du-toit-as-dominee-toe-uiteindelik-gekies-vir-die-slang/

Kok, J. \& Jordaan, B., 2019, 'The metanarraphors we lead and mediate by: Insights from cognitive metaphor theory in the context of mediation in a VUCA world', in J. Kok \& S.C. van den Heuvel (reds.), Leading in a VUCA world: Integrating leadership, spirituality and discernment, bl. 1-26, Springer, Cham.

Kok, J. \& Van den Heuvel, S.C., 2019 (reds.), Leading in a VUCA world: Integrating leadership, spirituality and discernment, Springer, Cham.

Kuitert, H., 2002, Het algemeen betwijfeld christelijk geloof, Ten Have, Baarn.

Makka, A., 2019, 'Spirituality and leadership in a South African context', in J. Kok \& S.C. van den Heuvel (reds.), Leading in a VUCA world: Integrating leadership, spirituality and discernment, bl. 77-90, Springer, Cham.

Nel, M., 2020, 'African Pentecostal spirituality as a mystical tradition: How regaining its roots could benefit Pentecostals', HTS Teologiese Studies/Theological Studies 76(4), a5904. https://doi.org/10.4102/hts.v76i4.5904

Oosthuizen, J., 2020, Gesprek tussen Jean Oosthuizen en Ben du Toit in 2020, besigtig 08 Januarie 2021, vanaf https://youtu.be/e90f7SbLpGk

Rohr, R., 2011, Falling upward: A spirituality for the two halves of life, Jossey-Bass, San Francisco, CA.

Schneiders, S.M., 2000, Religion and spirituality: Strangers, rivals, or partners? California Public Lecture, Feb. 6, 2000, vol. 6, no. 2, Santa Clara University, Santa Clara, Cal.

Steenkamp, J., 2018, An integrated theory \& psychotherapy for trauma-spectrum manifestations, SHIP, Pretoria.

Tacey, D., 2012, 'Contemporary spirituality', in M. Cobb, C.M. Pulchaiski, B. Rumbold (reds.), The Oxford textbook of spirituality in healthcare, pp. 474-476, Oxford University Press, New York, NY.

Van den Broeck, H. \& Jordaan, B., 2018, The agile leader's scrapbook, LannoCampus, Leuven.

Verhaeghe, P., 2009, 'De moderne mens is niet verdeeld, hij is verbrokkeld', De Morgen, 02 September 2009.

Vertovec, S., 2007, 'Superdiversity and its implications', Ethnic and Racial Studies 30(6), 1024-1054.

Waaijman, K., 2002, Spirituality: Forms, foundations, methods, Peeters, Dudley, MA.

Žižek, S., 2020, Pandemic!: COVID 19 shakes the world, OR Books, New York, NY. 